\title{
Pemahaman Konsep Sifat Jari-Jari Atom Dan Keelektronegatifan Pada Mahasiswa Pendidikan Kimia Semester IV Tahun Ajaran 2016/2017 Hasil Pembelajaran Menggunakan Model Discovery Learning
}

\author{
Ruli Meiliawati \\ Program Studi Pendidikan Kimia, FKIP, Universitas Palangka Raya, Indonesia \\ e-mail: rulisidauruk@yahoo.com, HP : +6285245343580
}

\begin{abstract}
Abstrak : Model discovery learning merupakan kata lain pembelajaran penemuan. Sesuai dengan namanya, model ini mengarahkan mahasiswa untuk dapat menemukan sesuatu melalui proses pembelajaran. Mahasiswa diarahkan terbiasa menjadi sainstis. Tujuan penelitian ini adalah untuk mendeskripsikan Pemahaman Konsep Sistem Periodik Unsur Hasil Pembelajaran Menggunakan Model Discovery Learning pada Mahasiswa Semester IV Program Studi Pendidikan Kimia Tahun Ajaran 2016/2017. Penelitian ini melibatkan 47 mahasiswa Semester IV Program Studi Pendidikan Kimia Tahun Ajaran 2016/2017. Data hasil pemahaman konsep mahasiswa ditelusuri melalui pemberian tes tertulis terberbentuk essay terhadap mahasiswa sebelum dan sesudah menggunakan model discovery learning. Data dianalisis dengan teknik deskriptif. Hasil penelitian menunjukkan Pemahaman mahasiswa Semester IV Program Studi Pendidikan Kimia Tahun Ajaran 2016/2017 tentang Sistem Periodik unsur hasil pembelajaran menggunakan model discovery learning adalah (1) pemahaman konsep mahasiswa dalam menjelaskan kecendrungan jari-jari atom unsur seperiode atau segolongan dalam sistem periodik unsur sebelum pembelajaran sebanyak $51,06 \%$ mahasiswa tidak memiliki pemahaman dan setelah pembelajaran sebanyak $89,35 \%$ mahasiswa, terjadi perubahan pemahaman konsep, dan sebanyak 38,29\% mahasiswa tidak mengalami perubahana pemahaman; (2) menjelaskan kecenderungan keelektronegatifan dan setelah pembelajaran sebanyak $75,86 \%$ mahasiswa mampu membuktikan mengurutkan dan menjelaskan kecenderungan keelektronegatifan.
\end{abstract}

\section{Kata Kunci : Deskriptif, Discovery Learning, Sistem Periodik Unsur}

\section{Pendahuluan}

Pendidikan adalah proses untuk memberikan manusia berbagai macam situasi yang bertujuan memberdayakan diri sehingga banyak hal yang dibicarakan ketika kita membicarakan pendidikan. Aspek-aspek yang biasanya paling dipertimbangkan antara lain : (a) penyadaran, (b) pencerahan, (c) pemberdayaan, dan (d) perubahan perilaku. Pengertian pendidikan dalam arti luas maksudnya pendidikan adalah hidup, pendidikan adalah segala pengalaman belajar yang berlangsung dalam segala lingkungan dan sepanjang hidup.

Pengertian pendidikan secara sempit adalah pendidikan yang identik dengan sekolah. Berkaitan dengan hal tersebut, pendidikan merupakan pengajaran yang diselenggarakan di sekolah sebagai lembaga tempat mendidik (mengajar). Pendidikan merupakan segala pengaruh yang diupayakan sekolah terhadap anak dan remaja (usia sekolah) yang diserahkan kepadanya (sekolah) agar mempunyai kemampuan kognitif dan kesiapan mental yang sempurna dan berkesadaran maju yang berguna bagi mereka untuk terjun ke masyarakat, menjalin hubungan sosial, dan memikul tanggung jawab mereka sebagai individu maupun sebagai makhluk sosial (Soyomukti, 2013).

Salah satu materi yang dibahas dalam perkuliahan telaah kurikulum kimia adalah sifat keperiodikan unsur. Materi ini memiliki konsep-konsep akan saling berhubungan sehingga mahasiswa sangat dituntut untuk memahami konsep-konsep dasar. Pada pokok bahasan sifat keperiodikan unsur mahasiswa dituntut tidak hanya menghafal sifat-sifat yang ada tanpa memahami konsep sebenarnya tetapi mahasiswa dituntut mampu 
menjelaskan konsep sifat keperiodikan tersebut. Pendekatan pembelajaran model Discovery learning diharapkan mampu membangkitkan mahasiswa dalam menemukan konsep, dengan rangkaian sintak kegiatan penemuan di mana masalah dikemukakan dosen kemudian mahasiswa bekerja untuk menemukan jawaban terhadap masalah tersebut dengan bimbingan dosen.

Fokus Penelitian ini adalah mendeskripsikan Peningkatan kompetensi mahasiswa Pendidikan Kimia P.MIPA FKIP Universitas Palangka Raya Tahun Ajaran 2016/2017 sebagai calon guru dalam Memahami Konsep Sifat Keperiodikan Unsur Hasil Pembelajaran Menggunakan Model Discovery Learning.

Tujuan khusus penelitian ini adalah untuk: (1) mengembangkan Rencana Pelaksanaan Pembelajaran dengan model discovery learning, (2) mendeskripsikan pemahaman konsep sistem periodik unsur hasil pembelajaran menggunakan model discovery learning pada mahasiswa semester IV program studi pendidikan kimia Tahun Ajaran 2016/2017.

Keutamaan Penelitian ini adalah mendeskripsikan Peningkatan kompetensi mahasiswa Pendidikan Kimia P.MIPA FKIP Universitas Palangka Raya Tahun Ajaran 2016/2017 sebagai calon guru dalam Memahami Konsep Sifat Keperiodikan Unsur Hasil Pembelajaran Menggunakan Model Discovery Learning.

Model discovery learning merupakan nama lain dari pembelajaran penemuan. Sesuai dengan namanya, model ini mengarahkan mahasiswa untuk dapat menentukan sesuatu melalui proses pembelajaran. Mahasiswa diarahkan untuk terbiasa menjadi saintis. Mereka tidak hanya sebagai konsumen, tetapi diharapkan pula bisa berperan aktif, bahkan sebagai pelaku dari pencipta ilmu pengetahuan. Prinsip belajar dalam discovery learning adalah materi atau bahan pelajaran yang akan disampaikan tidak disampaikan dalam bentuk final akan tetapi mahasiswa sebagai peserta didik didorong untuk mengidentifikasi apa yang ingin diketahui dilanjutkan dengan mencari informasi sendiri kemudian mengorgansasi atau membentuk (konstruktif) apa yang mereka ketahui dan mereka pahami dalam suatu bentuk akhir.

Langkah-langkah model pembelajaran discovery learning yaitu: (1) perencanaan, (2) pelaksanaan. Kegiatan inti untuk model penemuan adalah sebagai berikut: (1) merumuskan masalah, (2) identifikasi masalah dengan membuat jawaban sementara (hipotesis), (3) mengumpulkan data, (4) pengolahan data (Data Processing), (5) pembuktian (Verification), (6) perumusan kesimpulan (generalization). Materi kimia yang dipelajari dalam pembelajaran discovery learning mencakup konsep-konsep tentang: sifat keperiodikan unsur, jari-jari atom, energi ionisasi, afinitas elektron, dan keelektronegatifan.

\section{Metode Penelitian}

Penelitian ini merupakan jenis penelitian deskriptif. Penelitian ini melibatkan 47 mahasiswa Semester IV Program Studi Pendidikan Kimia Tahun Ajaran 2016/2017. Data yang dikumpulkan pada penelitian ini berupa: pemahaman konsep sifat keperiodikan unsur hasil pembelajaran menggunakan model discovery learning yang ditelusuri melalui pemberian pre tes dan postes. Data pre tes dan pos tes dijaring menggunakan tes tertulis, di skor berdasarkan rubrik penskoran dan dihitung rerata skor mahasiswa, selanjutnya dideskripsikan pemahaman konsep siswa berdasarkan pola jawaban. Rincian kegiatan penelitian disajikan pada Tabel 1.

Tabel 1. Rincian Kegiatan Penelitian 


\begin{tabular}{|c|c|c|c|c|c|}
\hline Tahap & Kegiatan & Tujuan & $\begin{array}{l}\text { Teknik } \\
\text { pengumpulan data }\end{array}$ & $\begin{array}{l}\text { Instrumen } \\
\text { pengumpulan } \\
\text { data }\end{array}$ & $\begin{array}{l}\text { Teknik } \\
\text { analisis } \\
\text { data }\end{array}$ \\
\hline 1.Persiapan & $\begin{array}{l}\text { - Menyusun Rencana } \\
\text { Pelaksanaan Pembelajaran } \\
\text { - Menyusun lembar Kerja } \\
\text { Mahasiswa } \\
\text { - Menyusun instrumen pre } \\
\text { dan pos tes. }\end{array}$ & $\begin{array}{l}\text { Memproduksi Rencana } \\
\text { Pelaksanaan } \\
\text { Pembelajaran, } \\
\text { - Memproduksi lembar } \\
\text { Kerja Mahasiswa, } \\
\text { - Memproduksi instrumen } \\
\text { pre dan pos tes }\end{array}$ & $\begin{array}{l}\text { Menginventarisasi } \\
\text { RPP. Lembar kerja, } \\
\text { serta instrumen pre } \\
\text { dan pos tes }\end{array}$ & Dokumen & Deskriptif \\
\hline 2. Pre tes & $\begin{array}{l}\text { Menguji kemampuan awal } \\
\text { mahasiswa }\end{array}$ & $\begin{array}{l}\text { Mengetahui kemampuan } \\
\text { awal mahasiswa sebelum } \\
\text { mengikuti Pembelajaran }\end{array}$ & $\begin{array}{l}\text { Memberikan tes } \\
\text { pemahaman konsep }\end{array}$ & Tes tertulis & Deskriptif \\
\hline 3. Pembelajaran & $\begin{array}{ll}\text { - } & \text { Pemberian stimulus } \\
\text { - } & \text { Identifikasi masalah } \\
\text { - } & \text { Pengumpulan data } \\
\text { - } & \text { Pengolahan data } \\
\text { - } & \text { Pembuktikan/ Verifikasi } \\
\text { - } & \text { Menyimpulkan }\end{array}$ & \begin{tabular}{l}
\multicolumn{1}{c}{ Mengetahui: } \\
- Menyajikan masalah \\
- Kemampuan \\
mengidentifikasi masalah \\
- Kemampuan \\
mengumpulkan data \\
- Kemampuan mengolah \\
data \\
- Kemampuan \\
membuktikan \\
pembelajaran \\
- Kemampuan \\
menyimpulkan
\end{tabular} & $\begin{array}{l}\text { - Menginvertarisasi } \\
\text { hasil pekerjaan } \\
\text { mahasiswa pada } \\
\text { setiap tahap } \\
\text { kegiatan DL } \\
\text { - Mahasiswa } \\
\text { melakukan } \\
\text { presentasi }\end{array}$ & Dokumen & Deskriptif \\
\hline 4. Pos tes & $\begin{array}{l}\text { Menguji kemampuan akhir } \\
\text { mahasiswa }\end{array}$ & $\begin{array}{l}\text { Mengetahui kemampuan } \\
\text { akhir mahasiswa setelah } \\
\text { mengikuti DL }\end{array}$ & $\begin{array}{l}\text { Memberikan tes } \\
\text { kemapuan DL }\end{array}$ & Tes tertulis & Deskriptif \\
\hline
\end{tabular}

\section{Hasil Penelitian Dan Pembahasan}

Pretes dan postes diberikan kepada 47 orang mahasiswasemester IV angkatan tahun 2015 yangmemprogrammata kuliah telaah kurikulum kimia. Data pretes dan postes diperoleh dari tes pemahaman konsep mahasiswa yang terdiri dari 4 butir soal essay, skor maksimal dari 4 butir soal adalah 8 . Skor pretes dan postes yang diperoleh mahasiswa kemudian dikonversikan dalam bentuk persentase pemahaman. Persentase tersebut yang menjadi tolak ukur untuk menentukan pemahaman konsep mahasiswa. Pada pretes skor terendah yang diperoleh mahasiswa adalah 0 dan skor tertinggi adalah 1 . Pada postes, skor terendah yang diperoleh mahasiswa adalah 0 dan skor tertinggi adalah 2. Hasil pretes dan postes secara umum dilihat pada Tabel 2.

Data yang dikumpulkan pada penelitian ini berupa: pemahaman konsep sifat keperiodikan unsur hasil pembelajaran menggunakan model discovery learning yang ditelusuri melalui pemberian pre tes dan postes.

Pengambilan data dilaksanakan pada hari Senin Tanggal 18 September 2017 pada mahasiswa semester IV angkatan 2015 yang memprogram mata kuliah telaah kurikukulum kimia sebanyak 47 mahasiswa, dengan alokasi waktu 4 x 45 menit. Pelaksanaan pembelajaran dilakukan dalam 3 tahap, yaitu : (1) pretes, (2) pelaksaaan pembelajaran menggunakan model discovery learning stimulation yaitu: problem statement, data collection, data processing, verification, generalization, (3) postes.

Pretes dan postes diberikan kepada 47 orang mahasiswasemester IV angkatan tahun 2015 yang memprogram mata kuliah telaah kurikulum kimia. Kegiatan pembelajaran menggunakan model discovery learning diamati oleh 3 orang pengamat, yaitu 2 orang mahasiswa semester VI dan 1 orang mahasiswa semester VIII program studi Pendidikan Kimia. Tabel 3 menunjukkan bahwa pengelolaan proses pembelajaran yang dilakukan dapat diasumsikan telah sesuai dengan RPP yang dibuat dan berlangsung dengan baik.

Tabel 2. Data Persentase Pemahaman Konsep Mahasiswa Pada Pretes Dan Postes 
Jurnal Ilmiah Kanderang Tingang 10(1) (2019) 30-45 ISSN 2087-166X

Januari-Juni 2019
Fakultas Keguruan dan Ilmu Pendidikan

Universitas Palangka Raya

https://chem-upr.education/ojs

\begin{tabular}{|c|c|c|c|c|c|c|}
\hline \multirow{2}{*}{$\begin{array}{c}\text { Kode } \\
\text { Mahasiswa }\end{array}$} & \multirow{2}{*}{$\begin{array}{c}\text { Skor } \\
\text { Pretes }\end{array}$} & \multicolumn{2}{|c|}{ Pemahaman Konsep } & \multirow{2}{*}{$\begin{array}{c}\text { Skor } \\
\text { Postes }\end{array}$} & \multicolumn{2}{|c|}{ Pemahaman Konsep } \\
\hline & & Pretes $(\%)$ & Dikategorikan & & Postes (\%) & Dikategorikan \\
\hline 1 & 4 & 50 & Cukup & 4 & 50 & Cukup \\
\hline 2 & 4 & 50 & Cukup & 2 & 25 & Kurang \\
\hline 3 & 1 & 12,5 & Kurang Sekali & 4 & 50 & Cukup \\
\hline 4 & 4 & 50 & Cukup & 4 & 50 & Cukup \\
\hline 5 & 0 & 0 & Kurang Sekali & 4 & 50 & Cukup \\
\hline 6 & 4 & 50 & Cukup & 4 & 50 & Cukup \\
\hline 7 & 2 & 25 & Kurang & 0 & 0 & Kurang Sekali \\
\hline 8 & 2 & 25 & Kurang & 2 & 25 & Kurang \\
\hline 9 & 3 & 37,5 & Kurang & 7 & 87,5 & Sangat Baik \\
\hline 10 & 2 & 25 & Kurang & 3 & 37,5 & Kurang \\
\hline 11 & 2 & 25 & Kurang & 3 & 37,5 & Kurang \\
\hline 12 & 2 & 25 & Kurang & 6 & 75 & Baik \\
\hline 13 & 2 & 25 & Kurang & 5 & 62,5 & Baik \\
\hline 14 & 1 & 12,5 & Kurang Sekali & 4 & 50 & Cukup \\
\hline 15 & 3 & 37,5 & Kurang & 3 & 37,5 & Kurang \\
\hline 16 & 3 & 37,5 & Kurang & 4 & 50 & Cukup \\
\hline 17 & 4 & 50 & Cukup & 4 & 50 & Cukup \\
\hline 18 & 1 & 12,5 & Kurang Sekali & 2 & 25 & Kurang \\
\hline 19 & 1 & 12,5 & Kurang Sekali & 3 & 37,5 & Kurang \\
\hline 20 & 4 & 50 & Cukup & 4 & 50 & Cukup \\
\hline 21 & 4 & 50 & Cukup & 2 & 25 & Kurang \\
\hline 22 & 4 & 50 & Cukup & 4 & 50 & Cukup \\
\hline 23 & 2 & 25 & Kurang Sekali & 3 & 37,5 & Kurang \\
\hline 24 & 1 & 12,5 & Kurang Sekali & 4 & 50 & Cukup \\
\hline 25 & 2 & 25 & Kurang & 3 & 37,5 & Kurang \\
\hline 26 & 1 & 12,5 & Kurang Sekali & 4 & 50 & Cukup \\
\hline 27 & 1 & 12,5 & Kurang Sekali & 3 & 37,5 & Kurang \\
\hline 28 & 0 & 0 & Kurang Sekali & 4 & 50 & Cukup \\
\hline 29 & 2 & 25 & Kurang & 4 & 50 & Cukup \\
\hline 30 & 4 & 50 & Cukup & 4 & 50 & Cukup \\
\hline 31 & 1 & 12,5 & Kurang Sekali & 4 & 50 & Cukup \\
\hline 32 & 3 & 37,5 & Kurang & 3 & 37,5 & Kurang \\
\hline 33 & 1 & 12,5 & Kurang Sekali & 3 & 37,5 & Kurang \\
\hline 34 & 0 & 0 & Kurang Sekali & 3 & 37,5 & Kurang \\
\hline 35 & 4 & 50 & Cukup & 2 & 25 & Kurang \\
\hline 36 & 1 & 12,5 & Kurang Sekali & 4 & 50 & Cukup \\
\hline 37 & 1 & 12,5 & Kurang Sekali & 3 & 37,5 & Kurang \\
\hline 38 & 2 & 25 & Kurang & 3 & 37,5 & Kurang \\
\hline 39 & 0 & 0 & Kurang Sekali & 4 & 50 & Cukup \\
\hline 40 & 3 & 37,5 & Kurang & 2 & 25 & Kurang \\
\hline 41 & 1 & 12,5 & Kurang Sekali & 4 & 50 & Cukup \\
\hline 42 & 4 & 50 & Cukup & 3 & 37,5 & Kurang \\
\hline 43 & 4 & 50 & Cukup & 4 & 50 & Cukup \\
\hline 44 & 3 & 37,5 & Kurang & 4 & 50 & Cukup \\
\hline 45 & 3 & 37,5 & Kurang & 2 & 25 & Kurang \\
\hline 46 & 1 & 12,5 & Kurang Sekali & 4 & 50 & Cukup \\
\hline 47 & 3 & 37,5 & Kurang & 4 & 50 & Cukup \\
\hline \multicolumn{2}{|c|}{ Rata-Rata } & 29,13 & Kurang & & 43,85 & Cukup \\
\hline
\end{tabular}

Peningkatan pemahaman konsep didasarkan pada data hasil pretes dan postes mahasiswa. Butir soal pada pretes dan postes mewakili konsep-konsep Sistem periodik unsur, dimana setiap butir soal pretes dan postes memiliki kriteria penskoran.

Persentase pemahaman konsep mahasiswa pada indikator I yang ditelusuri dari butir soal 1 saat pretes dan postes berturut-turut adalah $24,47 \%$ dan $50 \%$, dari persentae tersebut membukikan terjadinya perubahan pemahaman konsep mahamahasiswa dari kurang menjadi baik. Indikator II yang ditelusuri dari butir soal 2 memiliki persentase pemahaman konsep saat pretes dan postes berturut-turut adalah $27,66 \%$ dan $36,17 \%$ dari persentase tersebut membuktikan terjadinya perubahan pemahaman konsep mahamahasiswa dari kurang menjadi cukup baik.

Tabel 3. Pengelolaan Pembelajaran Menggunakan Model Discovery Learning

\begin{tabular}{|c|c|c|c|}
\hline \multirow{2}{*}{ No } & \multirow{2}{*}{ Aspek Yang Diamati } & Terlaksana & \multirow{2}{*}{ Skor } \\
\hline & & Ya $\quad$ Tidak & \\
\hline 1 & Dosen memberikan salam. & $\sqrt{ }$ & 4 \\
\hline 2 & Dosen memeriksa kehadiran mahasiswa. & $\sqrt{ }$ & 4 \\
\hline 3 & $\begin{array}{l}\text { Dosen memberikan pretes secara individu kepada mahasiswa dan mengumpulkannya } \\
\text { setelah selesai. }\end{array}$ & $\sqrt{ }$ & 4 \\
\hline 4 & Dosen memberikan apersepsi. & $\sqrt{ }$ & 3 \\
\hline 5 & Dosenmemberiakan motivasi. & $\sqrt{ }$ & 3 \\
\hline
\end{tabular}


Jurnal Ilmiah Kanderang Tingang 10(1) (2019) 30-45

ISSN 2087-166X

Januari-Juni 2019
Fakultas Keguruan dan Ilmu Pendidikan

Universitas Palangka Raya

https://chem-upr.education/ojs

\begin{tabular}{|c|c|c|c|}
\hline \multirow{2}{*}{ No } & \multirow{2}{*}{ Aspek Yang Diamati } & Terlaksana & \multirow{2}{*}{ Skor } \\
\hline & & Ya $\quad$ Tidak & \\
\hline 6 & Dosen menyampaikan tujuan pembelajaran. & $\sqrt{ }$ & 4 \\
\hline 7 & Dosen memberikan Stimulation (Stimulasi/pemberian rangsangan) & $\sqrt{ }$ & 3 \\
\hline 8 & $\begin{array}{l}\text { Problem statement (pernyataan/identifikasi masalah), Dosen meminta mahasiswa } \\
\text { mengajukan pertanyaan yang berkaitan dengan Sistem Periodik Unsur }\end{array}$ & $\sqrt{ }$ & 3 \\
\hline 9 & $\begin{array}{l}\text { Data Collection (pengumpulan data), Dosen meminta mahasiswa membentuk } \\
\text { kelompok belajar yang terdiri dari } 4-5 \text { orang mahasiswa. }\end{array}$ & $\sqrt{ }$ & 3 \\
\hline 10 & Dosen memberikan LKS yang dikerjakan secara berkelompok. & $\sqrt{ }$ & 4 \\
\hline 11 & $\begin{array}{l}\text { Data Prosesing (Pengelolaan Data), Dosen membimbing diskusi kelompok agar } \\
\text { mahasiswa dapat mengisi LKS dengan tepat. }\end{array}$ & $\sqrt{ }$ & 4 \\
\hline 12 & $\begin{array}{l}\text { Verification (Pembuktian), Dosen meminta mahasiswa untuk membandingkan hasil } \\
\text { diskusi dengan materi yang ada dibuku teks kimia. }\end{array}$ & $\sqrt{ }$ & 3 \\
\hline 13 & $\begin{array}{l}\text { Generalization (Generalisasi), Dosen meminta masing-masing kelompok maju untuk } \\
\text { menyampaikan kesimpulan yang telah mereka temukan pada LKS. }\end{array}$ & $\sqrt{ }$ & 4 \\
\hline 14 & Dosen menegaskan dan menyempurnakan kesimpulan hasil diskusi. & $\sqrt{ }$ & 3 \\
\hline 15 & $\begin{array}{l}\text { Dosen memberikan postes kepada mahasiswa untuk mengerjakan secara individu dan } \\
\text { mengumpulkannya setelah selesai. }\end{array}$ & $\sqrt{ }$ & 4 \\
\hline 16 & Dosen memberikan salam penutup. & $\sqrt{ }$ & 4 \\
\hline
\end{tabular}

Tabel 4. Peningkatan Pemahaman Konsep Mahasiswa

\begin{tabular}{ccccc}
\hline Indikator & Butir Soal & \multicolumn{2}{c}{ Pemahaman konsep (\%) } & Perubahan pemahaman \\
\cline { 1 - 3 } & & Pretes & Postes & \\
\hline I & 1 & 24,47 & 50 & 25,53 \\
II & 2 & 35,11 & 44,68 & 9,57 \\
III & 3 & 24,47 & 42,55 & 18,08 \\
IV & 4 & 27,66 & 36,17 & 8,51 \\
\hline \multicolumn{2}{r}{ Rata-rata seluruh indikator } & 27,92 & 43,35 & 15,42 \\
\hline
\end{tabular}

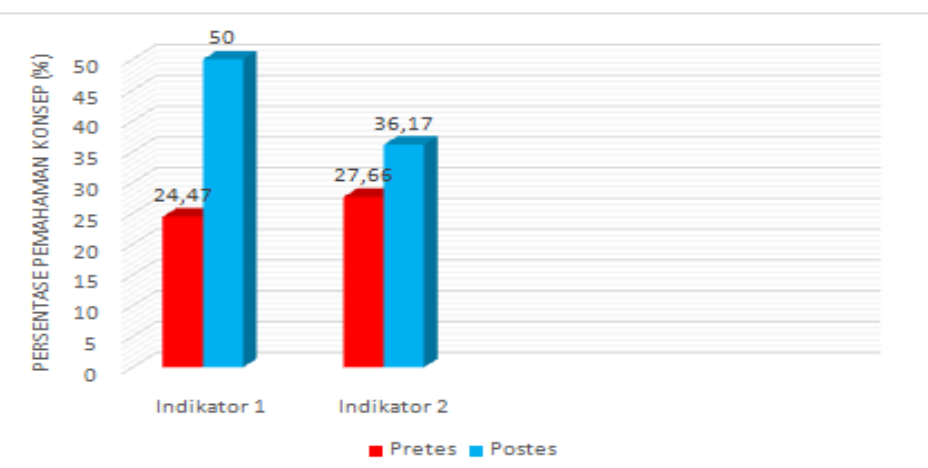

Gambar 5. Grafik Persentase Pemahaman Konsep Mahasiswa Pada saat Pretes dan Postes

Secara keseluruhan persentase pemahamana konsep mahasiswa pada materi Sifat Keperiodikan Unsur saat pretes dan postes berturut-turut adalah 27,92\% dan 43,35\% dari persentase tersebut terjadi perubahan pemahaman konsep dari kurang menjadi cukup baik. Adapun besarnya peningkatan pemahaman mahasiswa hasil pembelajaran yang diperoleh dari selisih persentase pretes dan postes pada keseluruhan indikator adalah $15,42 \%$. Hal ini menunjukkan bahwa pembelajaran menggunakan model discovery learning tidak mampu meningkatkan pemahaman konsep mahasiswa terhadap materi Sifat Keperiodikan Unsur. Grafik besarnya persentase pemahaman konsep mahasiswa pada saat pretes dan postes untuk setiap indikator dapat dilihat pada Gambar 5.

Tabel 5 adalah nilai mahasiswa saat pretes dan postes yang diurutkan mulai dari skor terendah ke skor tertinggi. Kurva menunjukkan hasil pembelajaran menggunakan model discovery learning mengalami perubahan pemahaman dari pretes ke postes.

Tabel 5. Skor Pretes dan Postes diurutkan dengan Nilai Terendah ke Tertinggi saat Pretes 


\begin{tabular}{|c|c|c|c|c|c|c|c|c|c|}
\hline \multirow{2}{*}{ Kode Mahasiswa } & \multicolumn{2}{|c|}{ Pretes } & \multicolumn{2}{|c|}{ Postes } & \multirow{2}{*}{ Kode Mahasiswa } & \multicolumn{2}{|c|}{ Pretes } & \multicolumn{2}{|c|}{ Postes } \\
\hline & Skor & $\%$ & Skor & $\%$ & & Skor & $\%$ & Skor & $\%$ \\
\hline 5 & 0 & 0 & 4 & 50 & 25 & 2 & 25 & 3 & 37,5 \\
\hline 28 & 0 & 0 & 4 & 50 & 29 & 2 & 25 & 4 & 50 \\
\hline 34 & 0 & 0 & 3 & 37,5 & 38 & 2 & 25 & 3 & 37,5 \\
\hline 39 & 0 & 0 & 4 & 50 & 9 & 3 & 37,5 & 7 & 87,5 \\
\hline 3 & 1 & 12,5 & 4 & 50 & 15 & 3 & 37,5 & 3 & 37,5 \\
\hline 14 & 1 & 12,5 & 4 & 50 & 16 & 3 & 37,5 & 4 & 50 \\
\hline 18 & 1 & 12,5 & 2 & 25 & 32 & 3 & 37,5 & 3 & 37,5 \\
\hline 19 & 1 & 12,5 & 3 & 37,5 & 40 & 3 & 37,5 & 2 & 25 \\
\hline 24 & 1 & 12,5 & 4 & 50 & 44 & 3 & 37,5 & 4 & 50 \\
\hline 26 & 1 & 12,5 & 4 & 50 & 45 & 3 & 37,5 & 2 & 25 \\
\hline 27 & 1 & 12,5 & 3 & 37,5 & 47 & 3 & 37,5 & 4 & 50 \\
\hline 31 & 1 & 12,5 & 4 & 50 & 1 & 4 & 50 & 4 & 50 \\
\hline 33 & 1 & 12,5 & 3 & 37,5 & 2 & 4 & 50 & 2 & 25 \\
\hline 36 & 1 & 12,5 & 4 & 50 & 4 & 4 & 50 & 4 & 50 \\
\hline 37 & 1 & 12,5 & 3 & 37,5 & 6 & 4 & 50 & 4 & 50 \\
\hline 41 & 1 & 12,5 & 4 & 50 & 17 & 4 & 50 & 4 & 50 \\
\hline 46 & 1 & 12,5 & 4 & 50 & 20 & 4 & 50 & 4 & 50 \\
\hline 7 & 2 & 25 & 0 & 0 & 21 & 4 & 50 & 2 & 25 \\
\hline 8 & 2 & 25 & 2 & 25 & 22 & 4 & 50 & 4 & 50 \\
\hline 10 & 2 & 25 & 3 & 37,5 & 30 & 4 & 50 & 4 & 50 \\
\hline 11 & 2 & 25 & 3 & 37,5 & 35 & 4 & 50 & 2 & 25 \\
\hline 12 & 2 & 25 & 6 & 75 & 42 & 4 & 50 & 3 & 37,5 \\
\hline 13 & 2 & 25 & 5 & 62,5 & 43 & 4 & 50 & 4 & 50 \\
\hline 23 & 2 & 25 & 3 & 37,5 & & & & & \\
\hline
\end{tabular}

Tabel 6. Deskripsi Pemahaman dan Skor Jawaban Pada Butir Soal 1

\begin{tabular}{ll}
\hline Skor & Deskripsi Pemahaman \\
\hline 0 & Mahasiswa tidak dapat mengurutkan dan menjelaskan kecenderungan jari-jari atom \\
1 & $\begin{array}{l}\text { Mahasiswa dapat mengurutkan jari-jari atom tetapi tidak dapat menjelaskan } \\
\text { kecenderungan jari-jari atom atau mahasiswa dapat mengurutkan jari-jari atom tetapi } \\
\text { dapat menjelaskan kecenderungan jari-jari atom }\end{array}$ \\
2 & Mahasiswa dapat mengurutkan dan menjelaskan kecenderungan jari-jari atom \\
\hline
\end{tabular}

Tingkat pemahaman mahasiswa untuk indikator 1 pada pretes yaitu $24,47 \%$ kemudian perubahan pemahaman pada saat postes menjadi 50\% dari hasil persentase tersebut dapat dikatakan perubahan pemahaman mahamahasiswa sebesar 25,53\% setelah pembelajaran menggunakan model discovery learning.

Perubahan skor pada Tabel 7. menunjukka bahwa pemahaman mahasiswa meningkat dari pretes ke postes. Berikut tabel perubahan skor jawaban mahasiswa pada soal nomor 1.

Tabel 7. Perubahan Skor Jawaban Mahasiswa dalam Menjelaskan kecenderungan jarijari atom unsur seperiode atau segolongan dalam sistem periodic

\section{Pretes}

\begin{tabular}{cccccc} 
Pretes & \multicolumn{5}{c}{ Postes } \\
\hline Skor & $\begin{array}{c}\text { Jumlah } \\
\text { Mahasiswa }\end{array}$ & $\begin{array}{c}\text { Persentase } \\
\text { Mahaiswa } \\
(\%)\end{array}$ & Skor & $\begin{array}{c}\text { Jumlah } \\
\text { Mahasiswa }\end{array}$ & $\begin{array}{c}\text { Persentase } \\
\text { Mahasiswa } \\
(\%)\end{array}$ \\
\hline 0 & 24 & 51,06 & 0 & 5 & 10,63 \\
1 & 23 & 48,94 & 1 & 37 & 78,72 \\
& & & 2 & 5 & 10,63 \\
\hline
\end{tabular}

Tabel 7. memperlihatkan perubahan skor jawaban mahasiswa pada indikator menjelaskan kecendrungan jari-jari atom unsur seperiode atau segolongan dalam sistem periodik unsur, pada postes sebanyak 5 orang mahasiswa $(10,63 \%)$ memperoleh skor 0 yang membuktikan tidak terjadi perubahan pemahaman konsep pada mahasiswa, 37 
orang mahasiswa $(78,72 \%)$ memperoleh skor 1 dan 5 orang mahamahasiswa $(10,63 \%)$ memperoleh skor maksimal 2 yang artinya Perubahan skor jawaban mahasiswa menunjukkan bahwa pemahaman mahasiswa meningkat setelah pembelajaran menggunakan model discovery learning.

Tabel 12. Deskripsi Pemahaman dan Skor Jawaban Pada Indikator 2

\begin{tabular}{ll}
\hline Skor & Deskripsi Pemahaman \\
\hline 0 & Mahasiswa tidak dapat mengurutkan dan menjelaskan kecenderungan keelektronegatifan \\
1 & Mahasiswa dapat mengurutkan kecenderungan kelektronegatifan tetapi tidak dapat \\
& menjelaskan kecenderungan keelektronegatifan atau mahasiswa dapat menjelaskan \\
& kecenderungan keelektronegatifan tetapi tidak dapat mengurutkan kecenderungan \\
& keelektronegatifan \\
& Mahasiswa dapat mengurutkan dan menjelaskan kecenderungan keelektronegatifan \\
\hline
\end{tabular}

Pemahaman konsep mahasiswa dalam menjelaskan kecenderungan keelektronegatifan suatu unsur dalam sistem periodik unsur dinilai dari jawaban pada butir soal 2 . Skor yang diberikan pada butir soal 2 berada pada rentang $0-2$ dengan deskripsi pemahaman seperti pada Tabel 12.

Tabel 13. Perubahan Skor Jawaban Mahasiswa Pada Indikator Menjelaskan Kecenderungan Kelektronegatifan Suatu Unsur dalam Sistem Periodik Unsur

\begin{tabular}{llllll}
\multirow{2}{*}{$\begin{array}{l}\text { Jkor } \\
\end{array}$} & $\begin{array}{l}\text { Jumlah } \\
\text { Mahasiswa }\end{array}$ & $\begin{array}{l}\text { Persentase } \\
\text { Mahasiswa (\%) }\end{array}$ & Skor & $\begin{array}{l}\text { Jumlah } \\
\text { Mahasiswa }\end{array}$ & $\begin{array}{l}\text { Persentase } \\
\text { Mahasiswa (\%) }\end{array}$ \\
\hline 0 & 21 & 44,68 & 0 & 14 & 24,14 \\
1 & 26 & 55,32 & 1 & 32 & 65,52 \\
& & 2 & 1 & 10,34 \\
\hline
\end{tabular}

Tabel 13 adalah perubahan skor mahasiswa sebelum dan sesudah pembelajaran berbantuan LKS dengan menggunakan model discovery learning. Sebelum pembelajaran mahasiswa memperoleh skor 0 sebanyak $44,68 \%$ dan skor 1 sebanyak 55,32\%, bisa dikatakan bahwa semua mahasiswa memiliki pemahaman konsep mengenai kecenderungan keelektronegatifan suatu unsur dalam sistem periodik unsur, dan setelah pembelajaran menggunakan model discovery learning berbantuan LKS yang dikerjakan secara berdiskusi kelompok terjadi perubahan pemahaman konsep mahasiswa sebesar $8,51 \%$ yang termasuk dalam kategori sedang.

\section{Kesimpulan}

Berdasarkan hasil penelitian dan analisis data yang telah dilakukan dapat disimpulkan bahwa peningkatan pemahaman konsep Sistem Periodik Unsur Hasil Pembelajaran menggunakan model discovery learning pada setiap konsep adalah :

1. Pemahaman konsep mahasiswa dalam menjelaskan kecendrungan jari-jari atom unsur seperiode atau segolongan dalam sistem periodik unsur sebelum pembelajaran sebanyak 51,06\% mahasiswa tidak memiliki pemahaman dan setelah pembelajaran sebanyak $89,35 \%$ mahasiswa, terjadi perubahan pemahaman konsep, dan sebanyak $38,29 \%$ mahasiswa tidak mengalami perubahana pemahaman

2. Menjelaskan kecenderungan keelektronegatifan suatu unsure dalam system periodik unsur berdasarkan data hasil percobaan sebelum pembelajaran sebanyak $44,68 \%$ mahasiswa tidak dapat mengurutkan dan menjelaskan kecenderungan keelektronegatifan dan setelah pembelajaran sebanyak 75,86\% mahasiswa mampu membuktikan mengurutkan dan menjelaskan kecenderungan keelektronegatifan. 
3. Rata-rata pemahaman konsep mahasiswa Kimia hasil pembelajaran menggunakan model discovery learning pada materi Sistem Periodik Unsur adalah sebesar 15,42\% yang tergolong cukup.

\section{Daftar Pustaka}

Chang, Raymond. (2005). Kimia Dasar: Konsep-konsep Inti Edisi Ketiga Jilid 2. Jakarta : Erlangga.

Halonen, Deana (2013). Discovery Learning: A Case Study. Auspace. athabascau.ca/ bitstream/2149/1519/3/ Disccovery Learning.ppt (diambil tanggal 9 Maret 3013).

Hendarman. (2012). Kurikulum Pendidikan Guru Perlu Dievaluasi. (Kompas.com, 11 Juli 2012).

Hutton, Laura (tanpa tahun). Discovery Learning (and Assessment). http://www.docstoc.com/?doc_id=120643420\&download=1(diambil tanggal 8 Maret 2013)

Mackenziea, Alison M. \& Johnstone, Alex H., \& Brown, R. Iain F. (2003). Learning from Discovery Learning. University Chemistry Education; The Higher Education chemistry journal of the Royal Society of Chemistry; 7(1); 13 - 26.

Petrucci, Ralph.H. (1985). Kimia Dasar Prinsip dan Terapan Modern Edisi Keempat Jilid 1. Jakarta : Erlangga.

Surapranata, Sumarna (2012). Perencanaan Kebutuhan Guru Pendidikan Dasar 2012 (Makalah disampaikan pada Kegiatan Analisis Validasi Instrumen Dokumen Pembinaan Karir PTKSD dan Analisis Perencanaan Kebutuhan Guru. Summer Hills Bandung, 31 Oktober -2 November 2012).

Soyomukti, Nurani. (20113). Teori-teori Pendidikan.Yogyakarta : AR-RUZZ Media. 